\title{
マルエージング鋼の疲労特性に及ぼす時効条件と湿度の影響†
}

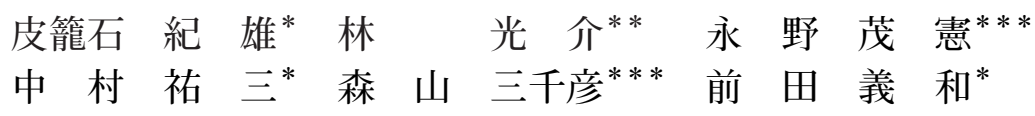

\section{Effects of Aging Condition and Humidity on Fatigue Properties of Maraging Steel}

\author{
by
Norio Kawagoishi ${ }^{*}$, Kosuke HaYashi ${ }^{* *}$, Takanori Nagano ${ }^{* * *}$, Yuzo Nakamura ${ }^{*}$, Michihiko MorIYAmA $^{* * *}$ and Yoshikazu MAEdA ${ }^{*}$

\begin{abstract}
In order to investigate the effects of aging condition and humidity on fatigue properties of $18 \% \mathrm{Ni}$ maraging steel of grade 350 , rotating bending fatigue tests were carried out in relative humidity of $25 \%$ and $85 \%$. Aging conditions selected were under- and peak-aging ones at conventional aging temperature of 753K. In addition, double aging treatments, that is, under- peak- and over-aging treatments at $673 \mathrm{~K}$ after the peak-aging at $753 \mathrm{~K}$ were also examined. Both of static and fatigue strengths were increased by the double aging. Although the fatigue strength was markedly decreased by high humidity in all of the steels, the decrease in fatigue strength due to high humidity was suppressed by the double aging. In all of the steels, the change in growth behavior of a crack was yielded around the crack length of a few grain sizes of prior austenite regardless of humidity. The growth rate of a crack longer than the above stated length was hardly influenced by the aging condition and humidity, while both of an initiation and its early propagation of a fatigue crack were accelerated by anodic dissolution in high humidity. These results were discussed from a point of view of the difference in precipitates depending on the aging condition.
\end{abstract}

Key words : Fatigue, Maraging steel, Aging condition, Humidity, Hardness, Rotating bending, Crack initiation, Crack propagation

\section{1 緒 言}

マルエージング鋼は実用鋼中最も静強度が高く，しか もじん性に優れた材料である。しかし高価なためその使用 範囲は限ずしも多くはない，すなわち，航空機やロケッ 卜, 人工衛星などの宇宙開発用機器, 身近には自動車の 無段変速機の金属べルト等, 特に過酷環境下において十 分な強度が要求される機器用部材として使用されること が多く, そこでは高強度だけでなく高い強度信頼性が求 められている。一般に高強度金属材料は, 久陷や湿度に 敏感であり, 1) 3) マルエージング鋼も同様である。そそのた め, 本鋼の切欠き感度については詳細な研究が行われて いる.著者らはこれまで，マルエージング鋼の基本的な 疲労特性の把握 5), 6)さらに疲労強度改善法について, 表 面处理 7) 9) と微視組織の調整 ${ }^{10)}$, 11) の両面から検討して きた。例えば微視組織の調整の面からは, 過時効処理に より逆変態オーステナイトを生成させれば度労強度は向 上すること，この効果は湿度に対する感度低下にも有効 であることを報告した。ささら本材の時効处理は通常所 定の温度と時間で一回だけ行うが, その時効に加えて, さらに比較的低温で再時効，すなわち二回目の時効を行 えば，湿度に対する感度は低下することも報告した ${ }^{12)} し$ かし，それに関する研究は他にみられず，著者らによる
限られたデータのみで，さらなるデータの蓄積が必要で ある.また湿度敏感性に対する二回の時効处理による効 果の詳細についても未解明であった。

そこで本研究では, 以上述べた著者らの結果を考慮し て，マルエージング鋼の時効条件を幅広く変えることに より, 静的な機械的性質と痩労特性を調べ, 通常の一回 の時効材に扔ける結果との比較のもとに二回目の時効処 理の影響，特に高湿度下に打ける疲労特性に対する二回 時効処理することの有効性を検討するため, 湿度を制御 した環境中で回転曲げ疲労試験を行い, 詳細なき裂伝ぱ 過程の表面観察と破面観察を行った。

\section{2 材料，試験片および実験方法}

用いた材料は市販の 350 級 $18 \% \mathrm{Ni}$ マルエージング鋼 （直径 $13 \mathrm{~mm}$ の丸棒）である. 化学成分を Table 1 に示 す. 納入材に, 溶体化処理 $(1123 \mathrm{~K}, 5.4 \mathrm{ks})$ を行った後, 各種時効組織を得るため時効条件を変えて熱処理した. 特に本研究では, 時効条件として通常適用される $753 \mathrm{~K}$ での 1 回の時効（以下，一段時効）に加え，その時効温 度で最高硬度を示した後さらに低温の $673 \mathrm{~K} て ゙ 2$ 回目の 時効（以下，二段時効）も行った。 なお，溶体化後の旧 オーステナイト平均結晶粒径は約 $20 \mu \mathrm{m}$ であった.

Fig. 1 に, 引張試験打よび度労試験に用いた試験片の

$\dagger \quad$ 原稿受理 平成 24 年 1 月 6 日 Received Jan. 6, 2012 (C) 2012 The Society of Materials Science, Japan

* 正 会 員 鹿児島大学大学院理工学研究科 干890-0065 鹿児島市郡元, Graduate School of Sci. and Eng., Kagoshima Univ., Korimoto, Kagoshima, 890-0065

** 鹿児島大学大学院理工学研究科 = 890-0065 鹿児島市郡元, Graduate School of Sci. and Eng., Kagoshima Univ., Korimoto, Kagoshima, 890-0065

*** 正 会 員 都城工業高等専門学校 干885-8567 都城市吉尾, Miyakonojo National College of Tech., Yoshio, Miyakonojo, 885-8567 
Table 1 Chemical composition (mass. \%).

\begin{tabular}{c|c|c|c|c|c|c|c|c|c|c}
\hline \hline Grade & $\mathrm{C}$ & $\mathrm{Si}$ & $\mathrm{Mn}$ & $\mathrm{Ni}$ & $\mathrm{Mo}$ & $\mathrm{Co}$ & $\mathrm{Ti}$ & $\mathrm{Al}$ & $\mathrm{Fe}$ \\
\hline $350 \mathrm{G}$ & 0.001 & 0.01 & 0.01 & 17.89 & 4.27 & 12.36 & 1.3 & 0.08 & Bal. \\
\hline
\end{tabular}

Table 2 Mechanical properties.

\begin{tabular}{c|l|c|c|c|c}
\hline \hline Material & \multicolumn{1}{|c|}{ Aging condition } & $\begin{array}{c}\text { Vickers hardness } \\
\mathrm{HV}\end{array}$ & $\begin{array}{c}0.2 \% \text { proof } \\
\text { stress } \\
\sigma_{0.2}(\mathrm{MPa})\end{array}$ & $\begin{array}{c}\text { Tensile strength } \\
\sigma_{\mathrm{B}}(\mathrm{MPa})\end{array}$ & $\begin{array}{c}\text { Reduction } \\
\text { of area } \\
\phi(\%)\end{array}$ \\
\hline SA-U1 & $753 \mathrm{~K}-11 \mathrm{ks}$ & 665 & 2194 & 2230 & 54 \\
\hline SA-U2 & $753 \mathrm{~K}-100 \mathrm{ks}$ & 690 & 2272 & 2310 & 54 \\
\hline SA-P & $753 \mathrm{~K}-150 \mathrm{ks}$ & 705 & 2300 & 2370 & 54 \\
\hline DA-U & $753 \mathrm{~K}-150 \mathrm{ks}+673 \mathrm{~K}-72 \mathrm{ks}$ & 750 & 2329 & 2418 & 52 \\
\hline DA-P & $753 \mathrm{~K}-150 \mathrm{ks}+673 \mathrm{~K}-400 \mathrm{ks}$ & 785 & 2420 & 2549 & 51 \\
\hline DA-O & $753 \mathrm{~K}-150 \mathrm{ks}+673 \mathrm{~K}-700 \mathrm{ks}$ & 750 & 2335 & 2436 & 55 \\
\hline
\end{tabular}

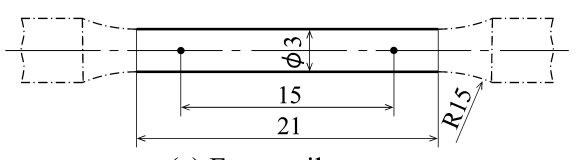

(a) For tensile test

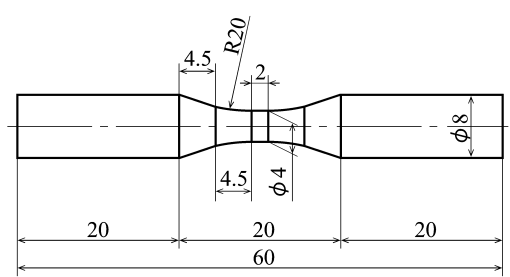

(b) For fatigue test

Fig. 1 Shape and dimensions of specimens (mm).

形状・寸法をそれぞれ示す。試験片は，溶体化処理した 後に機械加工し, その後時効処理を行ってから試験片表 面をエメリーペーパーにより研磨し，さらに表面の加工 影響層を電解研磨で約 $20 \mu \mathrm{m}$ 除去し最終仕上げとした。

用いた試験機は, 引張試験の場合オートグラフ AG-I (容量 $250 \mathrm{kN}$ ), 疲労試験の場合小野式回転曲げ疲労試験 機（容量 $15 \mathrm{~N} \cdot \mathrm{m}$, 繰返し速度約 $50 \mathrm{~Hz}$ ）である. 引張 試験は, 引張速度 $1 \mathrm{~mm} / \mathrm{min}$ の下, 大気中で, 疲労試験 は，相対湿度 (RH) $25 \%$ および $85 \%$ 中で行った。環境制 御下の湿度の精度は RH $\pm 5 \%$ であった。ここで上記の湿 度を選んだのは，両湿度とも日常的に生じうること, こ れまで行われた各種材料による研究で, 疲労強度に及ぼ す湿度の影響は 60 ～70\% を境に大きく変化することが 示されているので,13), 14)湿度 $25 \%$ は低湿度環境, 湿度 85\% は高湿度環境を代表できると判断したためである. 以下では，これらの湿度環境をそれぞれ低湿度，高湿度 と呼ぶ。な扔，試験環境に打ける温度はすべて室温であ り, 温度制御は行っていない。疲労過程に打ける試験片 表面の観察はレプリカ法で行った。 その際測定された表 面でのき裂長さ $\ell$ は試験片表面に沿う円周方向長さで定 義した。破面観察はSEMを,また時効組織の観察は TEM およびEDX を用いて行った。

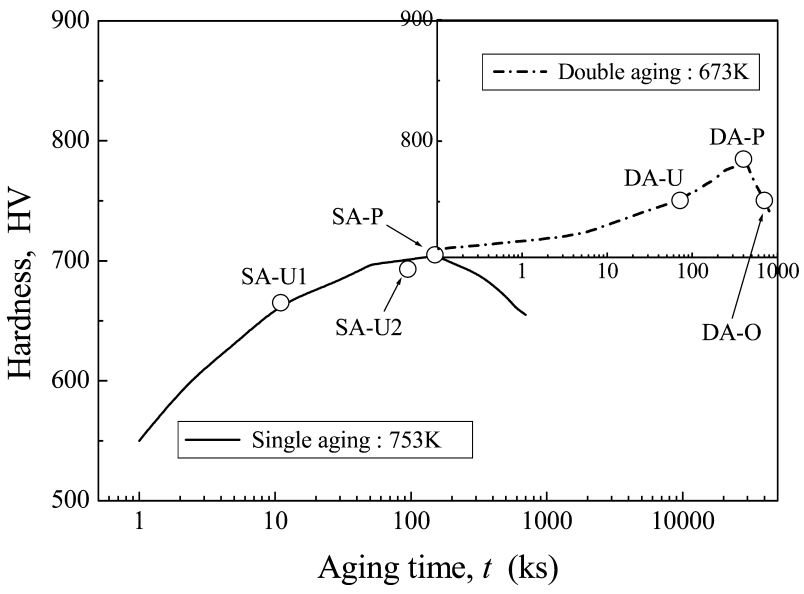

Fig. 2 Aging curves $(\bigcirc$ : selected conditions for tensile and fatigue tests).

\section{3 実験結果および考察}

\section{$3 \cdot 1$ 機械的性質に及ぼす時効組織の影響}

Fig. 2 に, 本研究で適用した時効条件における時効曲 線を示す。ここでは，一般に適用される時効温度， $753 \mathrm{~K}$ で一段目の時効を行い, 最高硬度に達した状態から, そ れより低い温度，673Kでさらに加熱する，つまり二段時 効处理も行った。このような時効を行うと硬さはさらに 増加し, ピークを示してから軟化している. 本研究では, 静的な機械的性質と疲労特性を調べる条件として，一段 時効では，不完全時効と完全時効，二段時効では，不完 全時効，完全時効打よび過時効条件を選んだ。これらの 条件を，時効曲線中に○印で示した，以下では，一段時 効を $\mathrm{SA}$, 二段時効を DA と記し, さらに時効状態として 不完全時効，完全時効打よび過時効をそれぞれ $\mathrm{U}, \mathrm{P}$ お よび O で表記する．また一段不完全時効材の場合 2 種類 の条件を選んだので，時効時間の短い順に 1,2 を付記 して区別する（例：一段, 不完全時効材で硬さが低い材 料を SA-U1 材).

Fig. 3 は，一段時効と二段時効の例として， SA-P 材 と DA-P 材の析出物の大きさと分布状態を示す TEM 写 
真である．両材の写真中白くみえる $30 \sim 50 \mathrm{~nm}$ の棒状 析出物は電子線回折により $\mathrm{Ni}_{3} \mathrm{Ti}$ であることが確認され, この他電解抽出分離法 ${ }^{15)}$ により $\mathrm{Ni}_{3} \mathrm{Mo}, \mathrm{FeMo}, \mathrm{Fe}_{2} \mathrm{Mo}$ も確認された。これらの析出物は SA-U1 材を除くすべて の材料で観察されたが，SA-U1 材では， $\mathrm{Ni}_{3} \mathrm{Mo}$ は確認さ れずMoのほとんどは固溶しているようであった.これは， 時効時間が短いため $\mathrm{Ni}_{3} \mathrm{Mo}$ の析出の前駆段階として $\mathrm{Mo}$

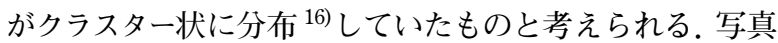
からわかるように, 全体としては SA-P 材に比べDA-P 材 の方が小さな析出物が増加し，広く分布しているようで ある。

Table 2 に各材の静的な機械的性質を示す。一段時効 で最高強度を示した後でも，二段時効を行えばさらに静 強度は増加し, しかも延性の低下はほとんどない。

Fig. 4 に一段時効材と二段時効材の例として, SA-P 材と DA-P 材で観察した引張破面の SEM 写真を示す. 両材共に，引張破面で観察される典型的なディンプル破 壊であるが，ディンプルの寸法は，DA-P材において小さ く，そしてその数は多い。これらの結果は，Fig. 3 に示 した TEM 観察で，二段時効材の方が微細な析出物が多 数分布していたことと対応している.

\section{$3 \cdot 2$ 疲労特性に及ぼす時効組織と湿度の影響}

Fig. 5 に低湿度と高湿度中における SA-U1 材，SA-P 材，DA-U 材および DA-P 材の S-N 曲線を示す。時効条 件により，疲労強度だけでなく湿度に対する感度も異な る。な打，破壊はすべて表面を起点に生じたので， $10^{7}$ 回 で破断しなかった試験片表面を観察したところ，すべて の試験片でき裂を確認することはできなかった。

Fig. 6 は, 各材の $10^{7}$ 回で定義した疲労限度とビッカー 不硬さの関係である。これまで各種高強度鋼で得られた 疲労限度と硬さの関係では，400HV 程度以上になると疲 労限度は低下することが多い. ${ }^{17)}$ しかし本研究の低湿度中 に扎ける結果では，二段時効を行うと静強度と同様に疲 労限度も一旦上昇し，この後完全時効さらに過時効にな

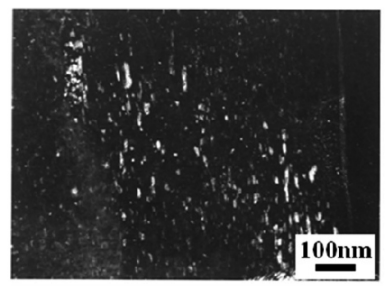

(a) SA-P

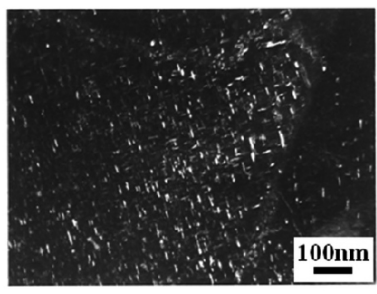

(b) DA-P
Fig. 3 Microstructures of SA-P and DA-P observed by TEM.

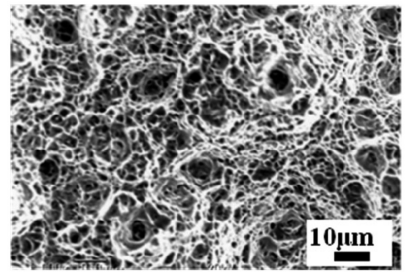

(a) $\mathrm{SA}-\mathrm{P}$

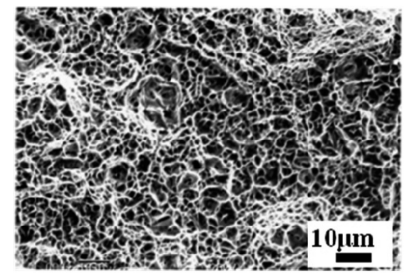

(b) DA-P
Fig. 4 Fracture surfaces of SA-P and DA-P after tensile test.

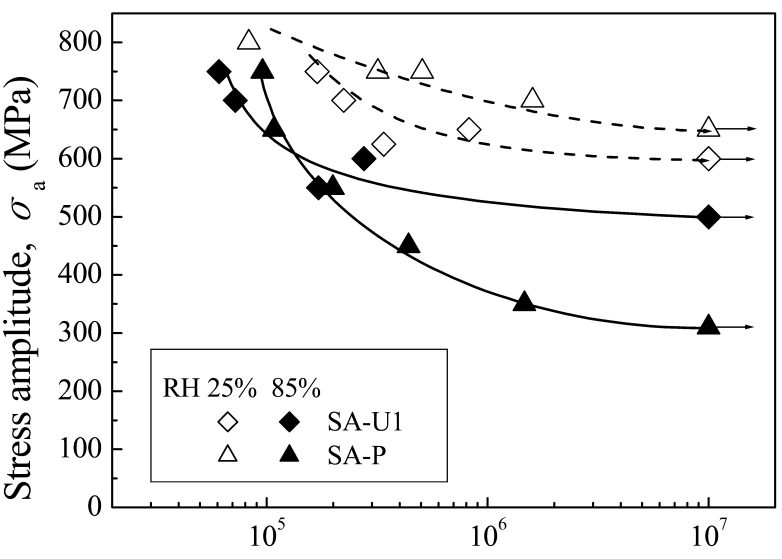

Number of cycles to failure, $N_{\mathrm{f}}$ (cycle)

(a)SA

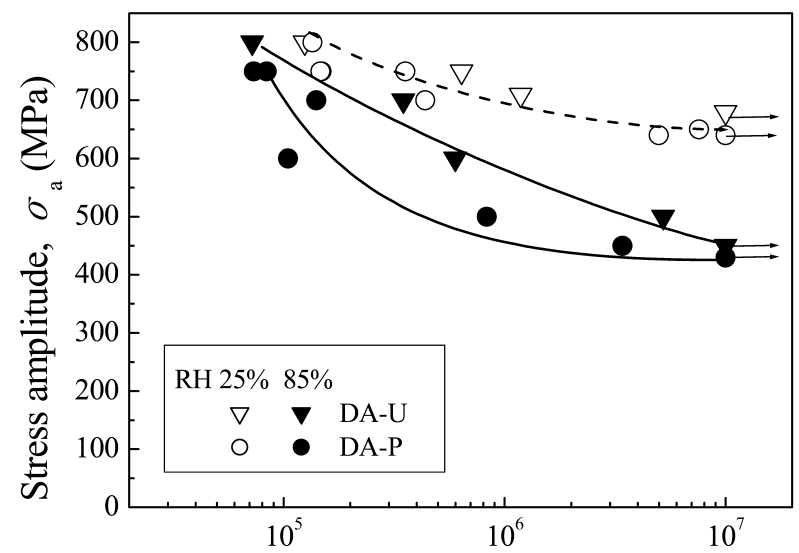

Number of cycles to failure, $N_{\mathrm{f}}$ (cycle) (b)DA

Fig. $5 S$ - $N$ curves.

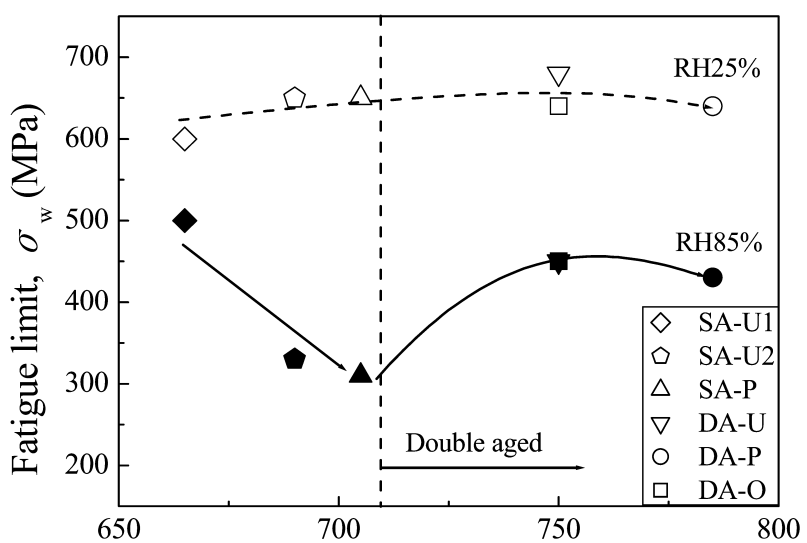

Hardness, HV

Fig. 6 Relation between fatigue limit and Vickers hardness.

るとわずかに減少するがその程度は非常に小さい.すなわ ち，硬さが $800 \mathrm{HV}$ 近傍まで疲労限度はほとんど低下しな い.このことより，硬さ上昇に伴う切欠き感度の上昇によ る疲労限度の低下 (例えば析出物サイズを引張破面のディ ンプル中で確認できた介在物の最大寸法である $10 \mu \mathrm{m}$ と し, 表面破壊に対する疲労限度を村上の式 $\left(\sigma_{\mathrm{w}}=0.45\right.$ $(\mathrm{HV}+960))^{4)}$ で推定すると，700HV に対し 800HVでは 
欠陥により約 $45 \mathrm{MPa}$ 低下する）を補う二段時効による 疲労抵抗の増加が示唆される。一方高湿度になると, 全 体的傾向として硬さの増加に伴い疲労限度の低下は大き くなるが，特に一段時効の完全時効 SA-P 材とその近傍 である SA-U2 材の強度低下が顕著である。しかし，二段 時効材ではさらに硬化したにも拘わらずその低下は減少 している. 以下では疲労強度に及ぼす時効の影響および 高湿度による疲労強度低下の原因を明らかにするため, 一段時効材の SA-P 材と二段時効材の DA-P 材抢よびDA$\mathrm{O}$ 材を対象に, 試験片表面に打ける疲労過程を連続的に 観察した.

Fig. 7 に,これらの材料のき裂伝ぱ曲線を示す.図 (b)は，応力繰返し数を破断繰返し数で基準化したもので ある. 各材のき裂発生時期は．高湿度中ではほとんど同 時期であるのに対し，低湿度中の場合多少異なるが。す べての材料で, 高湿度により, き裂発生は早くまた発生 初期のき裂伝ぱも加速されている。 そしてき裂発生時期 を全寿命に対するき裂発生寿命の割合で比較すると，す べての材料で, 低湿度中では $5 \sim 6$ 割程度, 高湿度中で は 1 ～割程度と高湿度によりき裂発生寿命の時期は大 幅に早期化している。しかし，それに対する時効による 相違はほとんど認められない。 ただ後で述べるように，

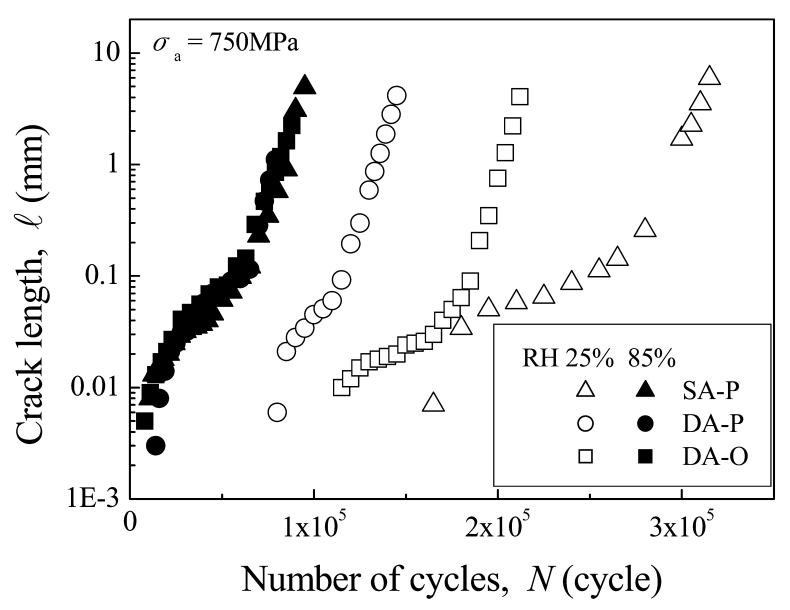

(a) $\ell-N$ curves

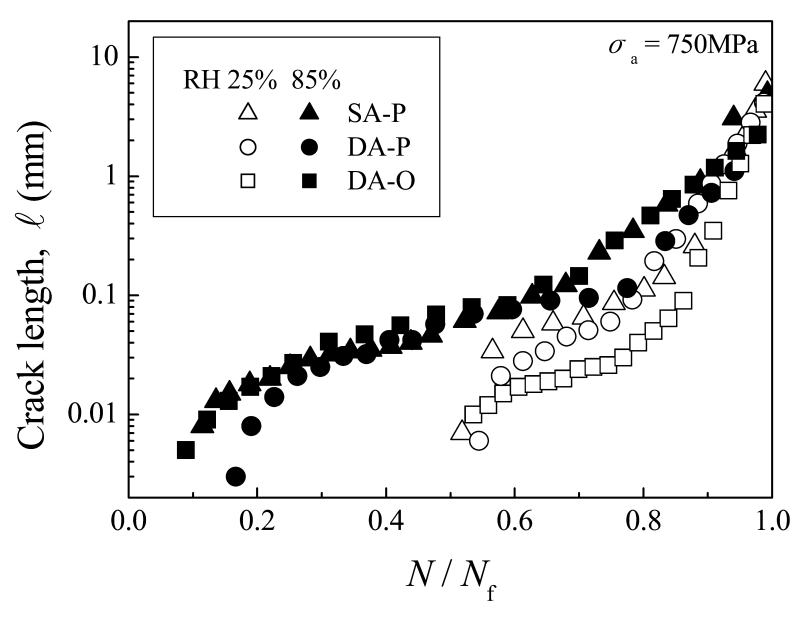

(b) $\ell-N / N_{\mathrm{f}}$ curves

Fig. 7 Crack growth curves of SA-P, DA-P and DA-O.
多くのき裂は, 電解研磨により生じたピットから発生し たため, 厳密な意味でのき裂発生時期は論じられない. しかし Fig. 7 の結果は, 高湿度によるき裂の発生さらに 初期伝ぱの加速は明白であることを示している。またい ずれの湿度中でも表面き裂の長さが $50 \mu \mathrm{m}$ 前後でき裂伝 ぱの停滞挙動が確認される。

Fig. 8 は, Fig. 7 より求めた各材のき裂伝ぱ速度と応 力拡大係数幅の関係である.すべての材料で, 低 $\Delta K$ 域, すなわち前述したき裂伝ぱの初期において高湿度により き裂伝ぱの加速が生じているが, $\Delta K$ が $10 \mathrm{MPam}^{1 / 2}$ 程度 以上になると，き裂伝ぱ速度に対する湿度打よび時効条 件の影響はほとんど認められない。な打，一段時効にお ける過時効处理により, 逆変態オーステナイトを生成さ せた場合，高湿度による疲労強度の低下は抑制されたが， その場合でもき裂の発生と初期伝ぱの抑制が主な理由で, その後の長いき裂の伝ぱに対する影響はほとんど認めら れなかった. ${ }^{10)}$ ，11)また酒井らも，不完全時効から過時効 まで幅広く時効条件を変え, 静強度の異なる材料を用い て円孔付き平板試験片におけるき裂伝ぱ挙動を調べ，き 裂伝ぱ抵抗に及ぼす時効条件の影響はほとんどないこと を報告している.18)

Fig. 9 は，Fig. 7 に示したき裂伝ぱ曲線を求めた試験 片の表面て観察したき裂形態を示すレプリカ写真である. 図中○印で示したき裂の起点からわかるように，き裂は 多くの場合湿度, 時効条件に関係なく, 試験片表面の加 工影響層を除去するために行った電解研磨により生じた 微小なピット（穴径約 $5 \sim 10 \mu \mathrm{m}$ ） から発生している. このことは，この程度の小さなピットであってもき裂発 生に影響することを意味している。しかし前述のように 高湿度になると，き裂発生は大幅に早まることは明らか である。一方発生後のき裂は, すべての材料で湿度に関 係なく試験片軸に垂直に直線的に伝ぱしている．ただ詳 細には，Fig. 10 に示すき裂の拡大写真からわかるよう に, 高湿度中のき裂は低湿度中でのそれに比べ, 多少幅 広であり, き裂縁が溶解した痕跡が認められる。

Fig. 11 は，高湿度中，長寿命域で破断した試験片表

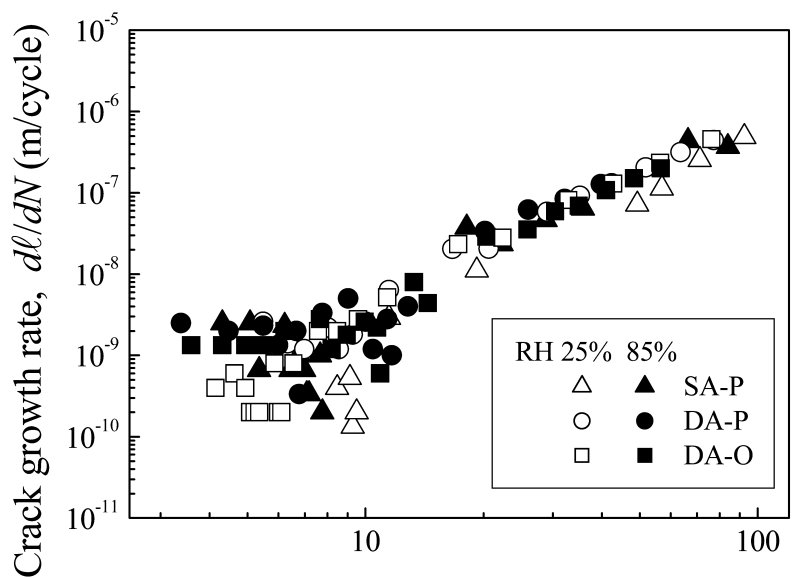

Stress intensity factor range, $\Delta K\left(\mathrm{MPa} \cdot \mathrm{m}^{1 / 2}\right)$

Fig. 8 Crack growth rate against to stress intensity factor range of SA-P, DA-P and DA-O. 


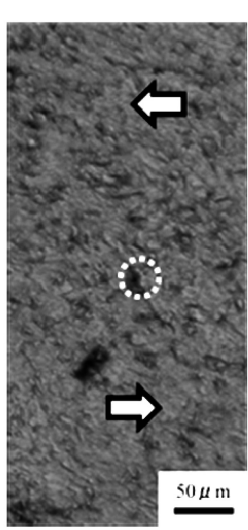

(a-1) RH25\%

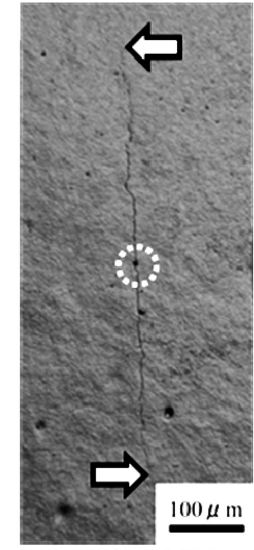

(a-2) RH85\%

(a) SA-P

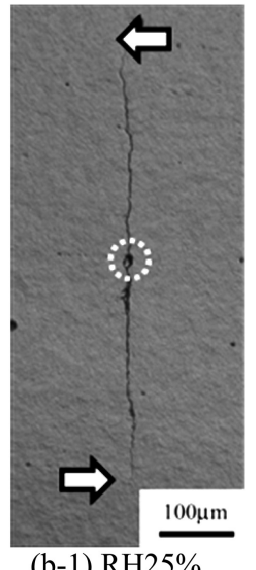

(b) DA-P

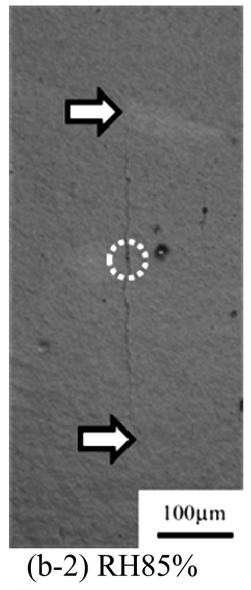

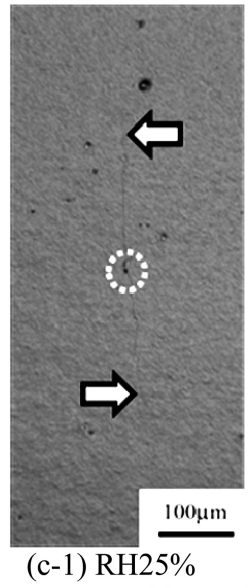

(c) DA-O

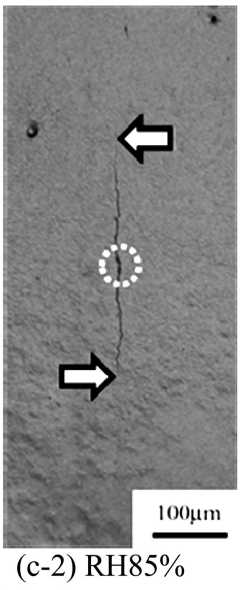

Fig. 9 Crack morphology of SA-P, DA-P and DA-O axial direction,

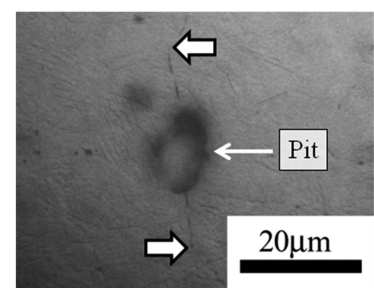

(a) $\mathrm{RH} 25 \%$ (crack initiated from pit yielded by electro polishing)

Fig. 10 Feature of crack ( $\vec{\supset}$ crack tip).

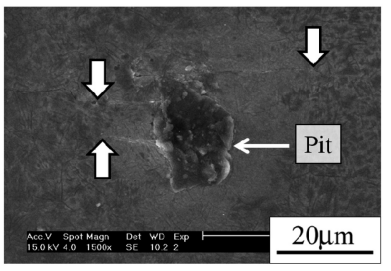

(a) Crack initiated from

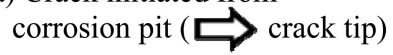

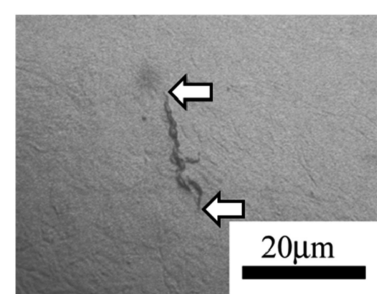

(b) RH85\% (dissolved crack)
Fig. 11 Surface state of specimen after about $10^{6}$ stress repetitions in high humidity.

面状態を観察したSEM 写真の一例である。(a) は非破 断部の表面状態を，(b) は破壊の起点近傍における破断 部のき裂縁を示している。これらの写真に示すように， 高湿度中の場合，試験片表面，そしてき裂縁には腐食痕 が多く観察され，腐食で生じた穴等の損傷部を起点に発 生したき裂も多く確認された。このことと，Fig. 10 に示 した高湿度中で伝ぱ過程のき裂縁に溶解の痕跡が認めら れたことを考慮すると, 高湿度によるき裂の発生と初期 伝ぱの促進は，アノード溶解によるものと考えられる。 このことについては, 後で改めて検討する.

Fig. 12 に，SA-P材，DA-P 材および DA-O 材の破面 写真を示す．観察箇所はすべて表面より約 $100 \mu \mathrm{m}$ 内部 の領域である。いずれの湿度でも，また時効条件でも破 面の多くはマルエージング鋼で一般的に観察されるすだ

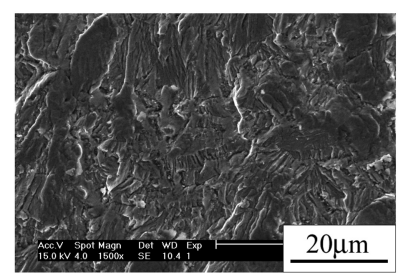

(a-1) RH25\%

(a) SA-P

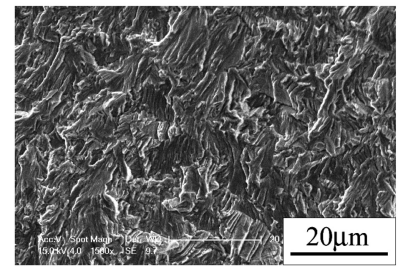

(b-1) RH25\%

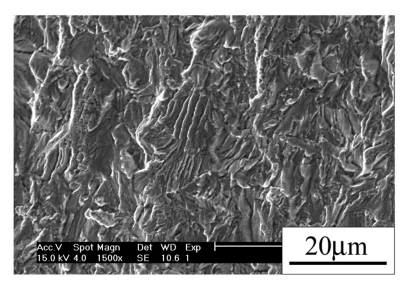

(a-2) RH85\%

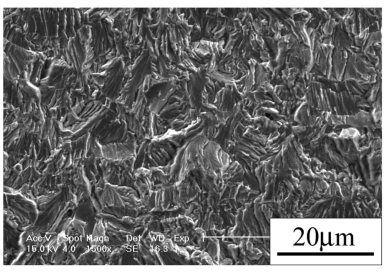

(b-2) RH85\%

(b) DA-P

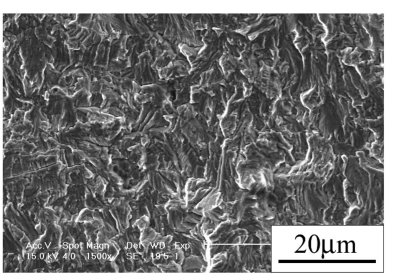

(c-1) RH25\%

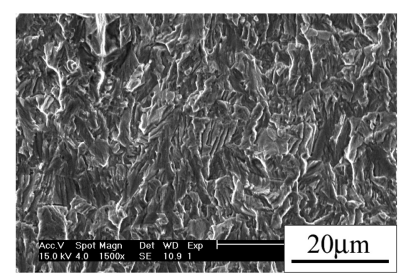

(c-2) RH85\% (c) DA-O

Fig. 12 Fracture surfaces.

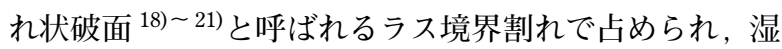
度および時効条件による相違はほとんど観察されなかっ た。このようなき裂伝ぱ機構に対する湿度と時効条件の 影響がないことは，Fig. 8 に示したき裂伝ぱ速度に対す る湿度および時効条件の影響が認められなかったことと 符合している.

\section{$3 \cdot 3$ 考察}

以上述べたように，マルエージング鋼に対し通常適用 される時效温度で最高強度を示した段階で, さらに低い 温度による二回目の時効処理（二段時効）を行うことに 
より, 静強度だけでなく, 程度は小さいものの㽻労強度 も改善され，しかも高湿度による強度低下も抑制される ことがわかった。このようなマルエージング鋼に対し二 段時効処理を行った例は, 著者らの知るところほとんど 報告されておらず, 従ってそれによる静強度や疲労強度 への影響に関する研究もみられない。そこで以下では, 上述した二段時効による疲労特性への影響について考察 する.

まず二段時効による静強度打よび疲労強度の改善につ いては次のようなことが考えられる．微視組織的な観察 精度は十分でなく更なる検討を要するものの，析出物の 大きさと分布状態を示した TEM 写真では，一段時効よ り二段時効の方が微細な析出物が多く分布していた。こ のことは引張破断で生じたディンプルの寸法と数にも反 映されていた。これは，Fe-Mo二元状態図から推測され るように, $753 \mathrm{~K}$ の一段時効より低い温度 $673 \mathrm{~K}$ で再時効 を行えばMoの固溶量は増加するので, 22) さらなる過飽和 $\mathrm{Mo}$ の析出扎よび $\mathrm{Fe}_{2} \mathrm{Mo}$ の析出が起り，それにより強度 上昇が生じたものと考えられる．実際このことを支持す るデータとして, Tewari らの研究がある.すなわち, 彼 らは，350 級 18\%Ni マルエージング鋼を用いて幅広い条 件下での時効処理を行い, それによる析出物の詳細な観 察を行っている。そして, 高温 (>723K) での析出物は $\mathrm{Ni}_{3}$ (Ti, Mo)であるのに対し, 低温 (<723K) の場合 $\mathrm{S}$ 相析 出の後時効時間の増加に伴い数ナノサイズの $\omega$ 相 ${ }^{23)}$ が組 織全体に析出し，さらに長時間になるとその中に $\mathrm{Fe}_{2} \mathrm{Mo}$ が析出することを報告している.24)また, Sha らも同様な 結果を得ており, $\omega$ 相の析出が硬さ上昇に寄与している ことを明らかにしている. ${ }^{25)}$ 以上のことから，二段時効に よる静強度および疲労強度の上昇は, 一段時効による析 出物に加え, 低温時効により析出した多くの微細な析出 物がさらなるすべり抵抗の増加に寄与したものと考えら れる。

次に高湿度による疲労強度の低下について検討する。 前述のように，き裂は低湿度の場合であっても，多くの 場合応力繰返し前から存在していた微小なピットから発 生したため, 厳密な意味でき裂発生に対する時効および 湿度の影響を評価するには十分ではない。したがって， ピットのない状態で, そして疲労強度に及ぼす湿度と時 効条件の影響が大きい低応力, 長寿命域でのき裂発生挙 動を確認する必要がある。しかしピットの存在について は, 本鋼はもともと $10 \mu \mathrm{m}$ 程度というピットサイズの介 在物を含むことからその影響は小さいものと考えられる. また Fig. 8 に示した結果は高応力下でのものであるもの の，き裂の発生初期を除けば，き裂伝ぱに対する湿度の 影響さらに時効組織の影響は非常に小さい. 換言すれば, 疲労強度に対する湿度の影響は, き裂の発生と初期伝ぱ で生じていると考えてよい.

Fig. 13 は，高湿度中で破壊した場合の破面中，き裂 発生起点に介在物が残っていた数例の中の一つを示す破 面写真である.介在物とマトリックスの境界は溶解し, その大部分は分離していることがわかる．このことと

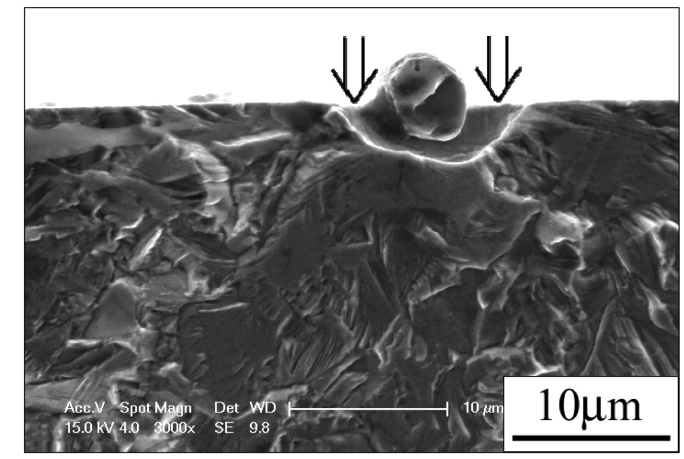

Fig. 13 Fracture surface around crack initiation site in high humidity (SA-P, $\Downarrow$ dissolved region).

Fig. 10 と Fig. 11 に示した高湿度中で, 腐食痕が多く観 察され，き裂はそこを起点に発生したこと，さらにその 際のき裂は腐食により幅広になっていたことから, 高湿 度中ではき裂発生と初期伝ぱがアノード溶解により加速 されたと考えてよい．このことは時効条件に関係なくす べての材料で共通に生じることである。しかし時効条件 により瘦労強度の湿度敏感性が異なり，とくに高湿度に よる疲労強度の低下が一段時効の完全時効あるいはその 近傍で最も顕著となった。この理由，あるいは二段時効 で改善された理由については現在のところ明らかでない が，次のようなことが推測される. Fig. 13 に示した介在 物とマトリックス境界での溶解，さらに前述したように き裂発生の多くが電解研磨で生じたピットであったこと を考慮すると, 応力負荷による応力集中部でのすべりの 増加, それによる腐食電位の変化がアノード溶解の促進, さらにき裂発生の促進に繋がったことを示唆している。な お，観察された他の介在物も含めEDXで分析したところ 介在物は TiCであることが確認された.このことから，こ の介在物は本鋼の製造過程でもともと含まれる化合物で, 一段目の時効以前から存在する介在物中粗大なものが観 察されたものと考えられる。述のようにアノード溶解の 原因が応力集中部における腐食電位の変化であると考え た場合，二段時効により疲労強度に対する高湿度の影響 が減少した理由として, 両時効材間におけるマトリック スの腐食電位の差に時効組織の違いが関係していること になる。そしてマトリックス中で一段時効と二段時効で 組織上異なる主な点は, 二段時効で微細析出物が増加し たことであり，応力集中源となる介在物およびピットは 両時効材間で差異はない. したがって, 両時効材におけ るマトリックス間の腐食電位の違いは, マトリックスが 微細析出物を含むか否かの違いとなり，それを含む方が すべり抵抗は高くまた電気化学的にも腐食電位は貴とな ることが推測され，アノード溶解の減少，それによるき 裂発生の遅れが二段時効による高湿度下での疲労強度低 下が小さくなった理由であると推測される。しかしこの ことについては, $\mathrm{TiC} の$ 腐食電位, 時効組織とアノード 溶解の関係等電気化学的観点からの検討が必要である.

ところで，湿度および時効条件に関係なく表面き裂の 長さが旧オーステナイト粒の数結晶粒程度である $50 \mu \mathrm{m}$ 
前後でき裂伝ぱの停滞あるいはき裂伝ぱ挙動の変化がみ られた。そこでき裂発生箇所近傍の詳細な破面観察を行っ た。その例を Fig. 14 に示す。き裂発生箇所近傍には， 旧オーステナイト粒径あるいはパケットサイズに相当す るフラットな破面がみられ，その後のラス割れとは伝ぱ 機構と破面の単位大きさは異なることがわかる．このこ とは Fig. 13 でも同様に確認でき，いずれの湿度でも， また時効条件でも同様であった。従って表面き裂の長さ が $50 \mu \mathrm{m}$ 前後で生じたき裂伝ぱ挙動の変化は, 上述した き裂長さによるき裂伝ぱの組織依存性およびそれに関係 した破面粗さ誘起き裂閉口効果に起因した挙動と考えら れる.

\section{4 結言}

マルエージング鋼の静的な機械的性質と疲労特性に及 ぼす時効条件および湿度の影響を調べるため, 大気中で の引張試験と相対湿度を $25 \%$ と $85 \%$ に制御した環境中で の回転曲げ疲労試験を行った。検討した時効条件は, 通 常適用される時効温度 $753 \mathrm{~K}$ 下での不完全および完全時 効（一段時効）とそれに加え，完全時効後さらに $673 \mathrm{~K}$ に温度を下げた条件下での不完全，完全時効および過時 効（二段時効）を含む，合計 6 種類の条件である. 主な 結果をまとめると以下のようになる。

（1）二段時効により，延性を損なうことなく静強度お よび疲労強度は上昇した。

（2）すべての時効条件で，疲労強度は高湿度により低 下したが，上記の二段時効を行えば疲労強度の低下は抑 制された。

（3）時効条件に拘わらず，き裂の発生およびその初期 伝ぱは高湿度により加速された。この主な理由はアノー ド溶解である。

（4）時効条件に拘わらず，そして両湿度中で，き裂長 さが旧オーステナイト粒径の数倍程度においてき裂伝ぱ の一時停滞が生じた。

（5）き裂の発生初期を除く長いき裂の伝ぱ抵抗は，時 効条件および湿度の影響をほとんど受けない.

（6）時効条件および湿度に関係なく，破面には，き裂 発生初期では旧オーステナイト粒径あるいはパケットサ イズのファセットが観察され，その後の伝ぱ領域で観察 されるラス割れとは破面の単位が異なった。このことが 結論 (4)の理由である.

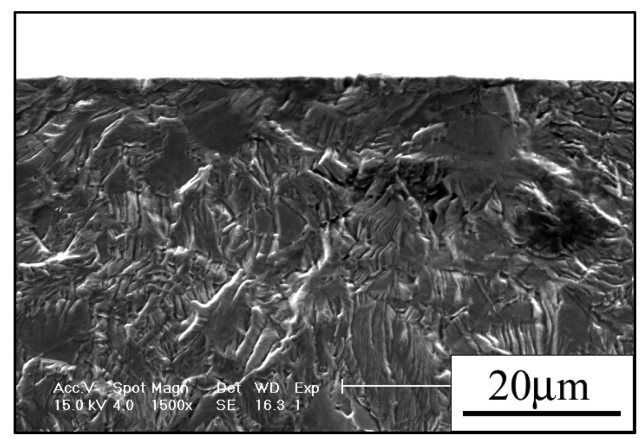

Fig. 14 Fracture surface in the region of the early growth of a crack in high humidity (SA-P).

\section{参 考 文 献}

1) M. F. Garwood, H. H. Zurburg and M. A. Ericson, Interpretation of tests and correlation with service, "Correlation of laboratory tests and service performance”, American Society for Metals, pp.1-77 (1951).

2) K. Endo, K. Komai, T. Fujimoto and Y. Matsuda, "Fatigue crack growth under stress corrosion of a high strength steel", Transactions of Japan Society of Mechanical Engineers, A, Vol45, No.398, pp.1152-1159 (1979).

3 ) Y. Murakami and M. Shimizu "Effects of nonmetallic inclusions, small defects and small cracks on fatigue strength of metals", Transactions of Japan Society of Mechanical Engineers, A, Vol.54, No.499, pp.413-425 (1983).

4) Y. Murakami, M. Abe and T. Kiyota, "Effects of small defects and inclusions on fatigue strength of maraging steel”, Transactions of Japan Society of Mechanical Engineers, A, Vol.53, No.492, pp.1482-1491 (1987).

5 ) M. Moriyama, S. Takaki and N. Kawagoishi, "Influence of aging condition and reversion austenite on fatigue property of the 300 grade $18 \mathrm{Ni}$ maraging steel", Journal of the Society of Materials Science, Japan, Vol.49, No.6, pp.631-637 (2000).

6) M. Moriyama, S. Takaki and N. Kawagoishi, "Influence of reversion austenite on fatigue property of $350 \mathrm{ksi}$ grade maraging steel”, Heat Treatment, Vol.41, No.5, pp.266-271 (2001).

7) N. Kawagoishi, K. Fukada, K. Morino, Q. Chen and E. Kondo, "Improvement of fatigue strength of maraging steel by Nitriding”, Transactions of Japan Society of Mechanical Engineers, A, Vol.67, No.654, pp.314-320 (2001).

$8)$ M. Moriyama, T. Nagano, N. Kawagoishi, S. Takaki and E. Nagashima, "Effect of shot peening on fatigue strength of maraging steel”, JSME Journal, Series A, Vol.44, No.2, pp.301308 (2001).

9) M. Moriyama, T. Nagano, N. Kawagoishi, S. Takaki and E. Nagashima, "Effect of double shot peening using super-fine particles on fatigue strength of $18 \% \mathrm{Ni}$ maraging steel", Transactions of Japan Society of Mechanical Engineers, A, Vol.67, No.656, pp.711-718 (2001).

10) T. Nagano, N. Kawagoishi, M. Moriyama, H. Nisitani and E. Kondo, "Influence of reversion austenite on notch sensitivity of maraging steel”, Transactions of Japan Society of Mechanical Engineers, A, Vol.68, No.676, pp.1724-1729 (2002).

11) T. Nagano, N. Kawagoishi and M. Moriyama, "Influence of reversion austenite initiation and propagation of fatigue crack of maraging steel”, Transactions of Japan Society of Mechanical Engineers, A, Vol.69, No.679, pp.663-639 (2003).

12) N. Kawagoishi, M. Miyazono, T. Nagano and M. Moriyama, "Effect of humidity on fatigue strength of maraging steels with different hardness", Journal of the Society of Materials Science, Japan, Vol.58, No.9, pp.787-792 (2009).

13) Haftirman, S. Hattori and T. Okada, "Fatigue strength of aluminum alloys in high-humidity environment", Transactions 
of the Japan Society of Mechanical Engineers, A, Vol.62, No.597, pp.1140-1145 (1996).

14) N. Kawagoishi, T. Fukudome, K. Kariya, Q. Chen and M. Goto, "Fatigue strength of age-hardened \& extruded $\mathrm{Al}$ alloy under high humidity (rotating bending and ultrasonic loading)”, Transactions of the Japan Society of Mechanical Engineers, A, Vol.76, No.772, pp.1651-1658 (2010).

15) Y. Okada, J. Endo and T. Nakayama, "Identification of the precipitation in maraging steels by non-aqueous electrolyte extraction method", Tetsu-toHagane, Vol.69, No.6, pp.703-710 (1983).

16) S. Takaki, Y. Sujita and Y. Tokunaga, "Calorimetric analysis of aging reaction in $\mathrm{Ni}$ maraging steels containing Ti”, Journal of Japan Institute of Metals, Vol.45, No.10, pp.1101-1106 (1981).

17) T. Sawai, Y. Kimura, K. Tsusaki, E. Takeuchi and S. Matsuoka, "High cycle fatigue properties of modified ausformed $1800 \mathrm{MPa}$-class spring steel”, Transactions of the Japan Society of Mechanical Engineers, A, Vol.68, No.665, pp.49-56(2002).

18) T. Sakai, K. Fujitani and T. Tanaka, "Effect of aging treatment on the fatigue crack propagation of $18 \% \mathrm{Ni}$ maraging steel", Transactions of Japan Society of Mechanical Engineers, A, Vol.44, No.383, pp.2175-2182 (1978).

19) M. Kobayashi, T. Hongoh and I. Sugiyama, "Crack growth resistance of $18 \% \mathrm{Ni}$ maraging steel in rotary bending fatigue", Transactions of Japan Society of Mechanical Engineers, A, Vol.49, No.442, pp.699-706 (1983).

20) M. Sumita, N. Maruyama and I. Uchiyama, "A fatigue fracture surface-analysis map of the $18 \mathrm{Ni}$ maraging steel”, Tetsu-Hagane, Vol.68, No.3, pp.451-460 (1982).

21) A. Nozue, T. Nose and T. Okubo, "Lath martensite boundary cracking in the vicinity of $\Delta \mathrm{K}_{\text {th }}$ for $18 \% \mathrm{Ni}$ maraging steel”, Journal of the Japan Institute of Metals, Vol.50, No.12, pp.1041-1048 (1986).

22) J. Houserova, J. Vrestal and M. Sob, "Phase diagram calculations in the Co-Mo and Fe-Mo systems using first-principles results for the sigma phase”, Computer Coupling of Phase Diagram and Thermochemistry, Vol.29, pp.133-139 (2005).

23) C. Servant, P. Lacombe and M. Griveau, "The ageing characteristics of an Fe-19 wt\% Ni-9 wt\% Co-5 wt\% W alloy”, Journal of Materials Science, Vol.15, pp.859-870 (1980).

24) R. Tewari, S. Mazumder, I. S. Batra, G. K. Dey and S. Banerjee, "Precipitation in $18 \mathrm{wt} \% \mathrm{Ni}$ maraging steel of grade 350”, Acta Materials, Vol.48, pp.1187-1200 (2000).

25) W. Sha, A. Cerezo and G. D. W. Smith, "Phase chemistry and precipitation reactions in maraging steels : Part III, Model alloys”, Metallurgical Transaction A, Vol.24, pp.12411249 (1993). 